\title{
Phanerozoic diamonds and decompression microstructures in eclogitic garnet and clinopyroxene from eastern Australia: Implications for continental crust-mantle development
}

\author{
B. Jane Barron ${ }^{1}$ and L. M. Barron ${ }^{2}$ \\ ${ }^{1}$ Consulting Petrologist, 7 Fairview Avenue, St Ives, NSW 2075, Australia \\ ${ }^{2}$ Research Associate, The Australian Museum, 6-8 College Street,Sydney, NSW 2010, Australia
}

Palaeoalluvial deposits in the Bingara-Copeton area, NSW, Australia, produced two million macrodiamonds (see map below).

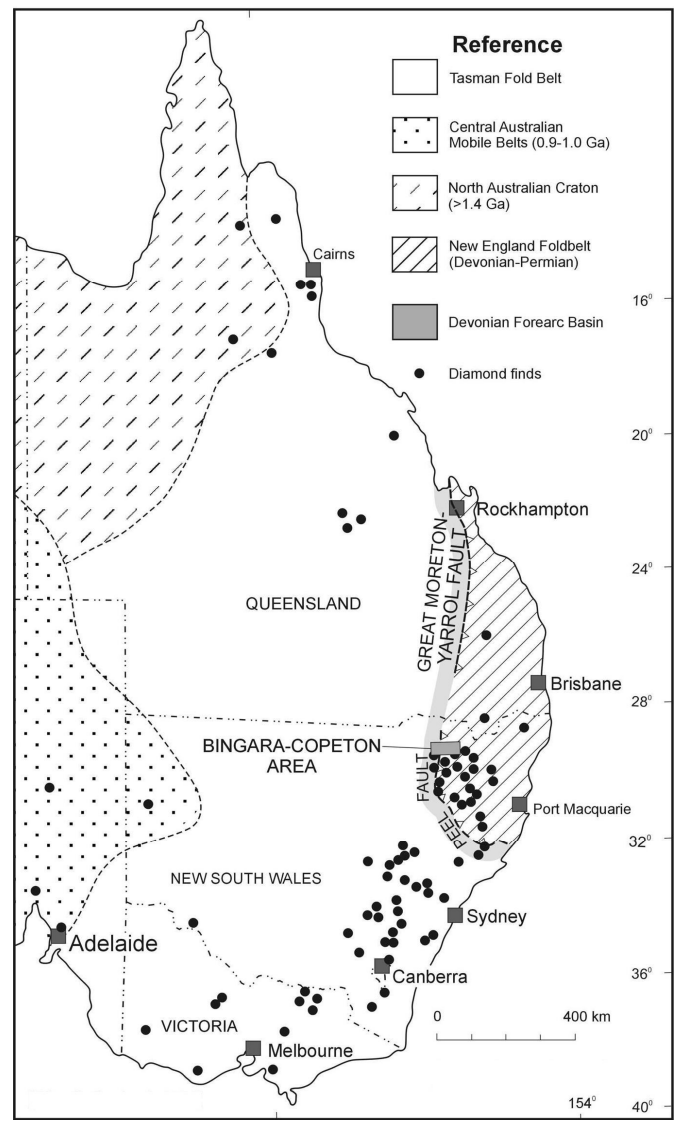

Located in the New England Foldbelt, a Phanerozoic greenschist facies accreted terrane, the deposits straddle a major fault zone $(1500 \mathrm{~km}$ long and extending down to the Moho, Korsch et al., 1997) that marks the trace of prolonged (mainly CarboniferousTriassic) subduction/ exhumation. Locally known as the Peel Fault, it is marked by abundant serpentinite mélange. Elsewhere the latter contains exhumed rare blocks of eclogite II, lawsonite eclogite and blueschist.

Exploration (Rimfire Pacific Mining NL) near Bingara (see next map) has revealed new diatremes, and recovered diamonds and compositionally unzoned mantle-formed UHP garnet xenocrysts of eclogite I, II, megacryst, UHP-crustal, and crustal types (Barron et ah.2005).

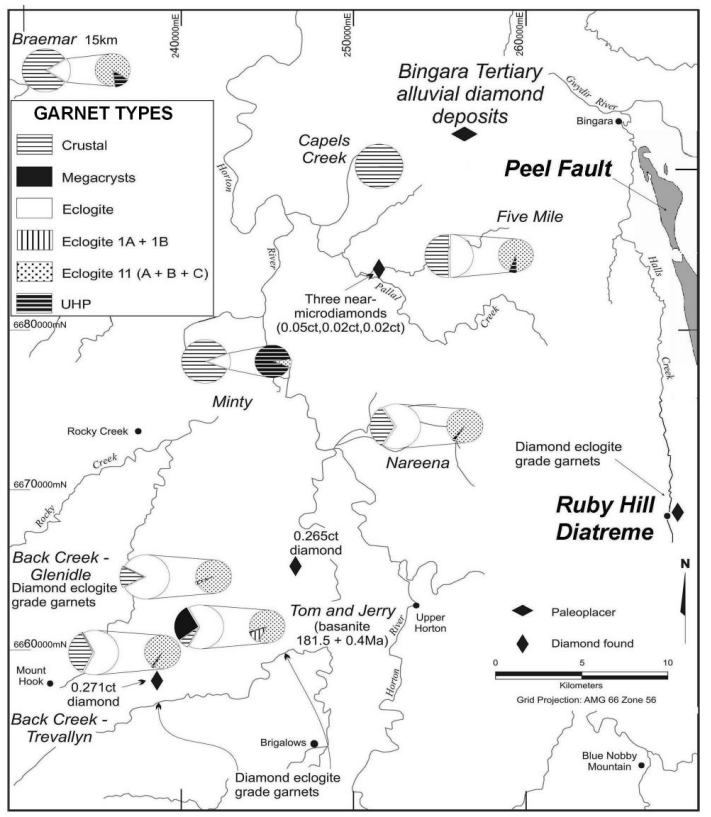

Macro-diamonds recovered by Rimfire are typical of Copeton-Bingara examples showing rounded, modified dodecahedral shapes with twin defects (naats), surface pits and microdisks. However three mini-diamonds (example A) are distinct and have skeletal pitted but subhedral angular shapes. (See photos below).
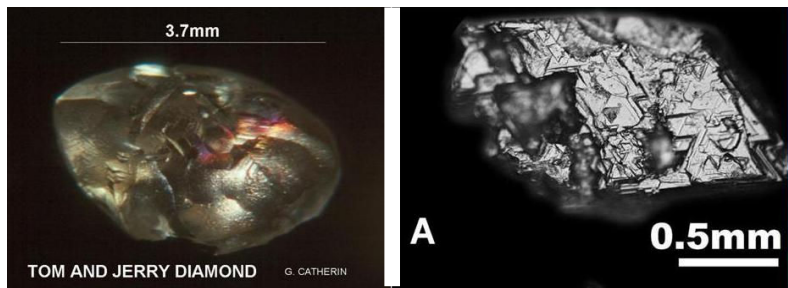

Some garnets show spectacular exsolution microstructures (see below) of crystallographically oriented rutile (a), ilmenite/ilmenite-rutile (b), apatite (c), pyrrhotite rods (d) and blebs (e).
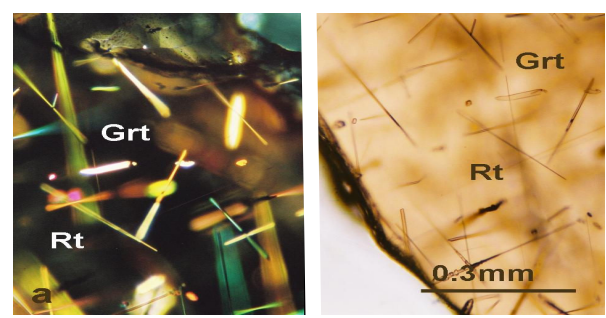

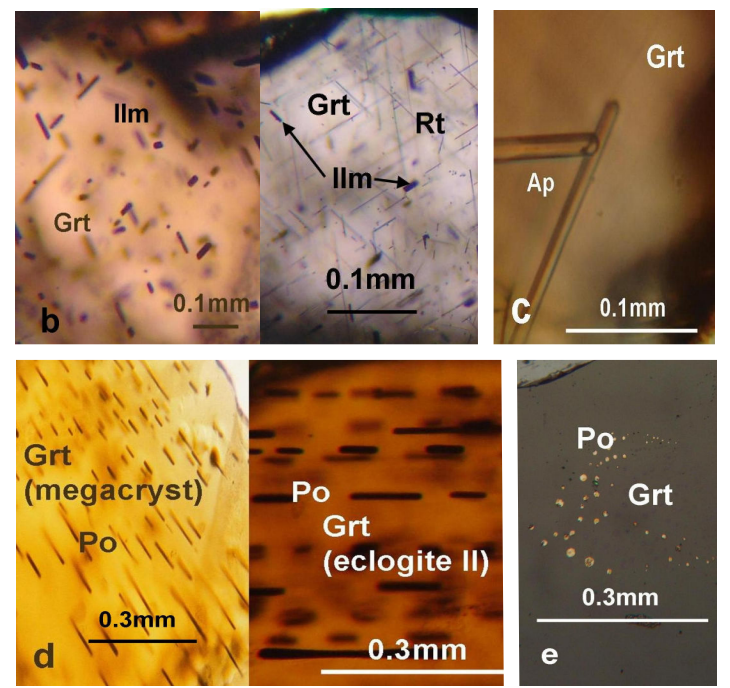

Garnets with exsolved rutile \pm quartz centrally are compositionally unzoned confirming re-equilibration and growth of a new rim under decompressed conditions (photo f, below).

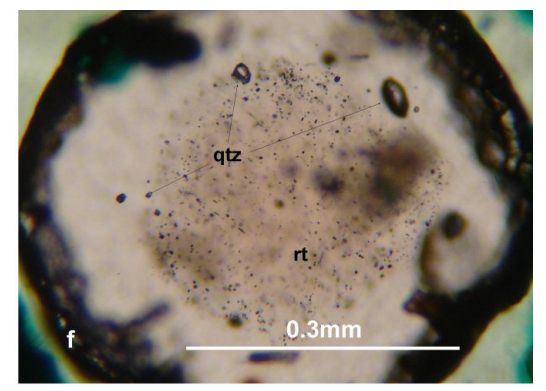

Clinopyroxene xenocrysts commonly contain exsolved plates of oriented Cr-spinel (photo g below).

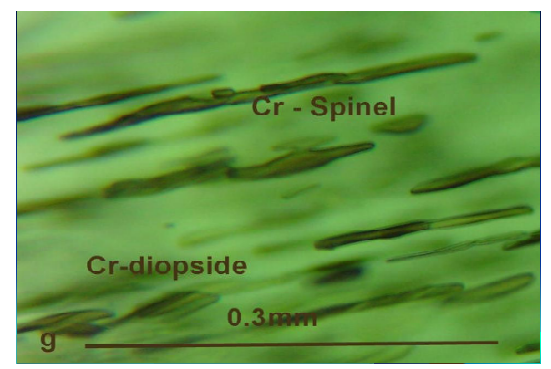

Corundum in 'super-aluminous' clinopyroxene (photo $\mathrm{h}$ below) occurs in a sapphirine-corundum-garnetclinopyroxene granulite xenolith (sample 820) from Ruby Hill diatreme, Bingara. Here, we interpret corundum as skeletal exsolutions in the clinopyroxene.

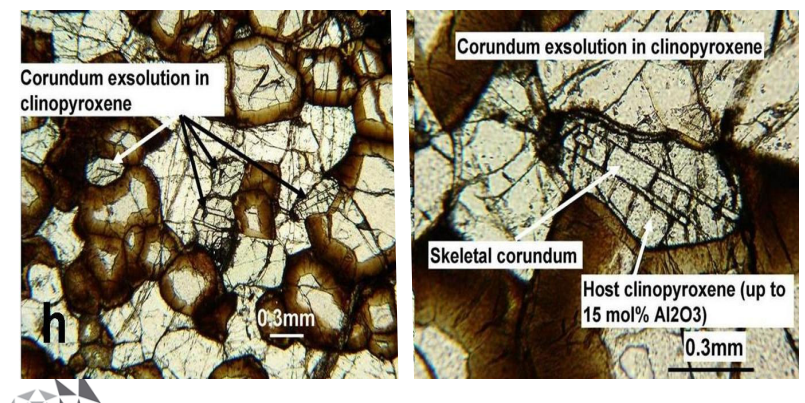

We also re-examine a xenolith of garnet pyroxenite (Roach 2004, his sample R152 from south of Canberra, $>750 \mathrm{~km}$ south of Bingara see locality map) and find complex mineral exsolutions (photo i below; cf. Huang et.al., 2007). Relict clinopyroxene porphyroblasts contain orthopyroxene and garnet ( \pm rare ilmenite) exsolution lamellae. Extinction of orthopyroxene lamellae is not parallel to their length, and some show multiple twins. Orthopyroxene porphyroblasts contain garnet ( \pm thin ?clinopyroxene) and sparse ilmenite exsolution lamellae. Garnet also occurs along grain boundaries, particularly in well equilibrated, recrystallised granular clino- and orthopyroxene domains (neoblastic necklace texture).
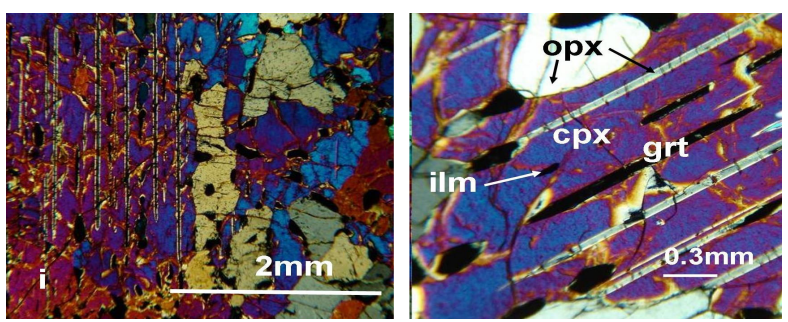

Exsolution microstructures in Bingara garnet and clinopyroxene indicate decompression by exhumation after formation in deeply subducted slab (possibly at $>3 \mathrm{Gpa}$ ). Decompression temperatures, calculated using analysed exsolutions in Bingara minerals and published calibrated thermometers, mainly are $<920^{\circ} \mathrm{C}$ (rutile in garnet, and also see plots below). Similar exsolution microstructures involving rutile and ilmenite in garnet from Norway were interpreted to represent previous 'super-titanic' UHP garnet, an analogue of 'supersilicic' majoritic garnet stable at diamond formation conditions c. $800^{\circ} \mathrm{C} / 3 \mathrm{GPa}$ (Van Roermund et al., 2000).
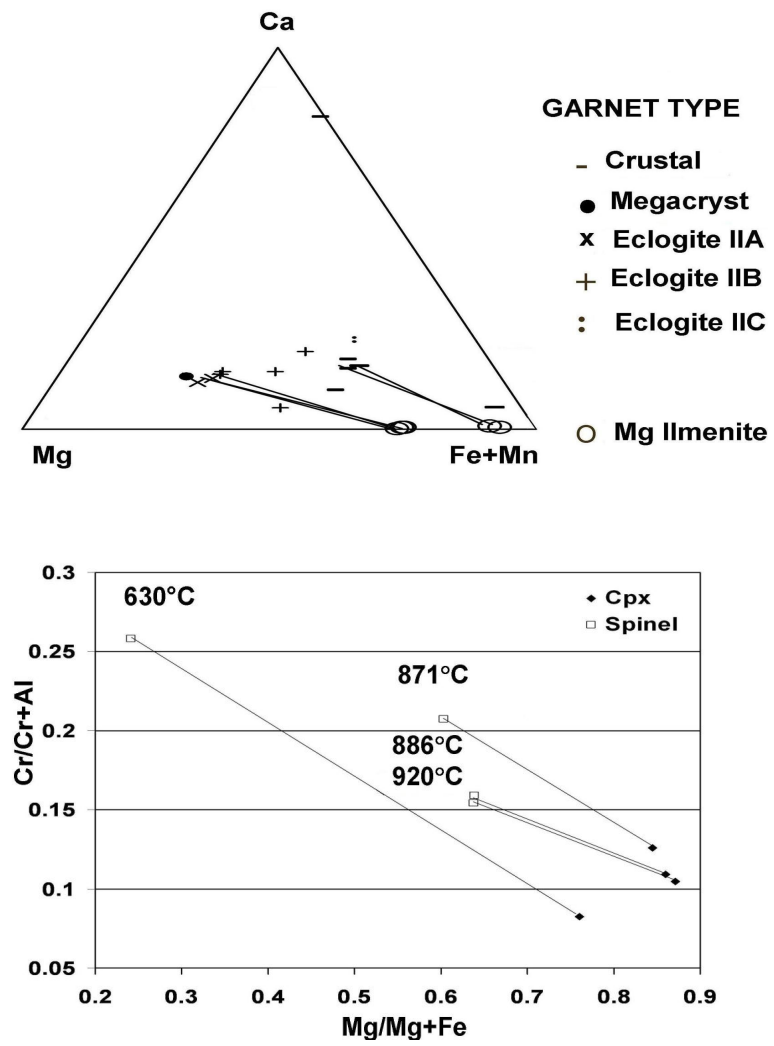
Ruby Hill xenoliths comprise coarse, granular, well equilibrated garnet pyroxenite \pm plagioclase, scapolite and spinel; spinel lherzolite; rare garnet websterite; garnet dunite; garnet harzburgite and meta-garnet anorthosite. Some are layered. Xenolith 820 (above) equilibrated at about $0.8 / 800 \mathrm{GPa} /{ }^{\circ} \mathrm{C}$ (Sutherland et al., 2003). Clinopyroxene compositions and estimated bulk composition of this xenolith compare closely with unusual "corundum-bearing garnet pyroxenite" in thin layers alternating with mylonitised peridotite from graphitised-diamond-bearing exhumed terranes of Beni Bousera (Morocco, Kornprobst et al., 1990) and Ronda, Spain (Morishita et al., 2003).

Roach (2004) calculated xenolith R152 (above) equilibrated at about $1.32 / 970 \mathrm{GPa} /{ }^{\circ} \mathrm{C}$. We interpret this texture as another example of decompression exsolution, possibly from a stalled subduction slab (or raft of crystallised mantle-derived magma) that experienced multi-stage partial exhumation (cf. Xu et al., 2004). Calculated $\mathrm{P} / \mathrm{T}$ for xenolith $\mathrm{R} 152$ therefore records the last recrystallisation at a very high mantle level prior to basaltic delivery. Other eastern Australian examples of exsolution in mantle xenoliths (including symplectites) are widespread (e.g. Irving, 1974; Wass et al., 1983; Griffin et al., 1984).

Xenocryst garnets at Bingara indicate areal and depth variation of dense UHP-eclogite and less dense felsic UHP-crustal lithologies in slab portions not buoyant enough to be completely exhumed. Exhumation is an efficient process for transporting diamonds and garnets (in insulated slab/blocks) upwards through the mantle. Buoyancy determines final stranded exhumation levels (shallow mantle or base of the crust), with some buoyant slab slivers forced into the lower crust via major faults such as the Peel. Shallow-mantle-sourced Mesozoic basanite volcanism completed the delivery.

A survey, of garnet analyses from mantle-formed rocks in 64 publications, showed that storage conditions (mantle versus exhumed into the crust) controlled the average $\mathrm{TiO}_{2}$ levels in garnet; mantle stored garnet had higher ( $\geq 0.17 \mathrm{wt} \%$ ) levels of $\mathrm{TiO}_{2}$ than crustal stored garnet. Most Bingara mantle-formed garnet was captured from slab stranded in the mantle, whereas exsolved and $\mathrm{TiO}_{2}$-poor garnet was derived from slab stranded in the crust. Alluvial diamonds recovered near concentrations of each type suggests diamond source regions existed at the two levels.

Exsolutions in garnet and clinopyroxene from exhumed terranes worldwide provide the most compelling evidence (apart from UHP diamonds) for exhumation of deeply subducted slab. We recognise similar exsolutions in xenocrysts/xenoliths from diatremes/ basalts in Phanerozoic subduction-accreted eastern Australia. These indicate widespread decompression, in minerals from exhumed (educted) UHP-slab slivers and recrystallised igneous rafts stranded at depth. Exsolution temperatures suggest re-equilibration at uppermost mantle/lower crustal levels. Therefore, we propose 'exhumation accretion' to the lower crust as an important continent-building process analogous to upper crustal subduction accretion. Exhumed UHP additions to the lower crust also explain the 'conventional' double-layer crustal architecture of Phanerozoic eastern Australia; of 'crystalline basement' at depth supporting and stabilising a thin skin of upper-crustal volcanic arc deposits.

\section{References}

Barron, B.J., Barron, L.M., Duncan, G., 2005. Eclogitic and Ultrahigh-Pressure Crustal Garnets and their relationship to Phanerozoic subduction Diamonds, Bingara area, New England fold belt, Eastern Australia. Economic Geology, 100, 1565-1582.

Griffin, W.L., Wass, S.Y., Hollis, J.D., 1984. Ultramafic xenoliths from Bullenmerri and Gnotuk Maars, Victoria, Australia: Petrology of a sub-continental crust-mantle transition. Journal of Petrology, 25, 53-87.

Huang, X.L., Xu, Y.G., Lo, C.H., Wang, R.C., Lin, C.Y., 2007. Exsolution lamellae in a clinopyroxene megacryst aggregate from Cenozoic basalt, Leizhou Peninsula, South China: petrography and chemical evolution. Contributions to Mineralogy and Petrology, 154, 691-705.

Irving, A.J., 1974. Geochemical and high pressure experimental studies of garnet pyroxenite and pyroxene granulite xenoliths from the Delegate basaltic pipes, Australia. Journal of Petrology, 15, $1-40$.

Kornprobst, J., Piboule, M., Roden, M., Tabit, A., 1990. Corundum-bearing garnet clinopyroxenites at Beni Bousera (Morocco): original plagioclase-rich gabbros recrystallised at depth within the mantle? Journal of Petrology, 31, 717-745.

Korsch, R.J., Johnstone, D.W., Wake-Dyster, K.D., 1997. Crustal architecture of the New England Orogen based on deep seismic reflection profiling. Geological Society of Australia Special Publication 19, 29-51.

Morishita, T., Arai, S., Gervilla, F., Green, D., 2003. Closed system geochemical recycling of crustal materials in alpine-type peridotite. Geochimica et Cosmochimica Acta, 67, 303-310.

Roach, I.C., 2004. Mineralogy, textures and P-T relationships of a suite of xenoliths from the monaro volcanic province, New South Wales, Australia. Journal of Petrology, 45 739-758.

Sutherland, F.L., Coenraads, R.R., Schwarz, D., Raynor, L.R., Barron, B.J., Webb, G.B., 2003. Al-rich diopside in alluvial ruby and corundum-bearing xenoliths, Australian and SE Asian basalt fields. Mineralogical Magazine, 67 (4), 717-732.

Van Roermund, H.L.M., Drury, M.R., Barnhoorn, A., De Ronde, A., 2000. Non-silicate inclusions in garnet from an ultra-deep orogenic peridotite. Geological Journal, 35, 209-229.

Wass, S.Y., Hollis, J.D., 1983. Crustal growth in southeastern Australia-evidence from lower crustal eclogitic and granulitic xenoliths. Journal of Metamorphic Geology, 1, 25-45.

Xu, W., Liu, X., Wang, Q., Lin, J., Wang, D., 2004. Garnet exsolution in garnet clinopyroxenite and clinopyroxenite xenoliths in Early Cretaceous intrusions from the Xuzhou region, eastern China. Mineralogical Magazine, 68, 443-453. 